Estuarine, Coastal and Shelf Science

March 2015, Volume 154, Pages 214-223

http://dx.doi.org/10.1016/i.ecss.2014.12.037

http://archimer.ifremer.fr/doc/00248/35885/

(c) 2015 Elsevier Ltd. All rights reserved.

\title{
High spatial variability of phytoplankton assessed by flow cytometry, in a dynamic productive coastal area, in spring:the eastern English Channel
}

\author{
Bonato Simon ${ }^{1,{ }^{*}}$, Christaki Urania ${ }^{1}$, Lefebvre Alain ${ }^{2}$, Lizon Fabrice ${ }^{3}$, Thyssen Melilotus ${ }^{4}$, \\ Artigas Luis Felipe ${ }^{1}$
}

${ }^{1}$ Université du Littoral Côte d'Opale, Laboratoire d'Océanologie et de Géosciences, CNRS UMR 8187 LOG, MREN ULCO, 32 av. Foch, 62930 Wimereux, France

${ }^{2}$ Ifremer LER/Boulogne, Laboratoire Environnement Littoral et Ressources Aquacoles, 150 Quai Gambetta BP 699, 62321 Boulogne sur Mer Cedex, France

${ }^{3}$ Université des Sciences et Technologies de Lille - Lille 1, Laboratoire d'Océanologie et de Géosciences, CNRS UMR 8187 LOG, Station Marine de Wimereux, 28 av. Foch, 62930 Wimereux, France

${ }^{4}$ Aix-Marseille Université, Mediterranean Institute of Oceanography MIO, UM110, CNRS/INSU IRD, 13288, Marseille, cedex 09, France

*Corresponding author : Simon Bonato, email address : simon.bonato@univ-littoral.fr

\begin{abstract}
:
The distribution of phytoplankton (from pico-to microphytoplankton) was investigated, at single-cell level and at high spatial resolution, during an oceanographic cruise across the eastern English Channel (EEC) between April 27 and 29, 2012. Seawater was continuously collected from surface waters and analysed on board at high frequency (one sample every $10 \mathrm{~min}$ ), by using a new generation of pulseshape recording scanning flow cytometer (CytoSense, Cytobuoy@). A Bray-Curtis matrix analysis based on phytoplankton composition allowed the discrimination of 4 communities. Within these communities, abundance, cell size as well as single cell and total red fluorescence of 8 phytoplankton groups were measured. Picoeukaryotes and Synechococcus spp. cells dominated the mid Channel and most of the English waters monitored, whereas waters off Eastbourne as well as French coastal waters (under remote and direct estuarine influence) were characterized by the dominance of Phaeocystis globosa haploid and diploid cells. Most of the total red fluorescence signal, which correlated with chlorophyll a concentrations, was attributable to P. globosa and, to a lesser extent, to diatoms. In addition to submesoscale variation within phytoplankton communities, the single-cell features within each phytoplankton group gave information about the physiological status of individual phytoplankton cells.
\end{abstract}

Keywords : Phytoplankton dynamics, high spatial resolution, flow cytometer, red fluorescence 


\section{Introduction}

Phytoplankton micro-organisms, which represent major primary producers and biogeochemical mediators, show a considerable degree of spatial heterogeneity and temporal variability in coastal temperate systems (Cloern, 1996, Jacquet et al., 2002, Sosik et al., 2003 and Martin et al., 2005). The variability in phytoplankton abundance, biomass and composition depends on nutrient concentrations (Niraula et al., 2007), light availability and water turbidity (Falkowski et al., 1985), as well as on temperature (Agawin et al., 2000), salinity (Ahel et al., 1996) and turbulence (Margalef et al., 1979 and Smayda and Reynolds, 2001). Together with biotic interactions such as grazing (Sautour et al., 2000, Grattepanche et al., 2011a and Grattepanche et al., 2011b), infection processes (Suttle et al., 1990) and competition/mutualism amongst species (Sazhin et al., 2007), these controlling factors shape phytoplankton community structure and succession in spatial and temporal scales. Phytoplankton monitoring approaches and techniques should be able to address phytoplankton composition and abundance at high frequency, in order to accurately account for the rate of environmental changes which lead to micro-organism patchiness and dynamics in aquatic systems (Cassie, 1963 and Martin et al., 2005). In coastal and open marine waters of the eastern English Channel (EEC), phytoplankton dynamics have been investigated by applying classical techniques as microscopy and experimentation (Gómez and Souissi, 2007, Schapira et al., 2008, Lefebvre et al., 2011, Grattepanche et al., 2011a, Grattepanche et al., 2011b and Hernández-Fariñas et al., 2013), pigment (Brunet et al., 1996 and Breton et al., 2000) and molecular analysis (Monchy et al., 2012 and Christaki et al., 
2014). Inverted optical microscopy is the reference tool to assess the community composition of major phytoplankton groups such as diatoms and dinoflagellates and has limitations for cells $<10 \mu \mathrm{m}$ or fragile cells that could be lost during fixation. Pigment analysis and molecular analysis provide useful information about broad phytoplankton pigmentary groups and whole community diversity, respectively. All of the above techniques are time consuming and cannot be applied to spatial or temporal surveys at high resolution, nor provide real time results. Recently, innovative techniques, such as spectral in vivo fluorescence, were applied in marine coastal systems, at high temporal (Houliez et al., 2012) or spatial resolution (Houliez et al., 2013), to follow the dynamics of up to four phytoplankton spectral (pigmentary) groups, including the haptophyte Phaeocystis globosa.

Amongst the innovative techniques employed to monitor phytoplankton semi-automatically, flow cytometry (FCM) is a powerful technology to investigate micro-organisms (Dubelaar and Jonker, 2000; Veldhuis and Kraay, 2000). FCM, by analysing single cells at a high rate (several thousand per second), can provide rapid quantifications of phytoplankton cells based on their fluorescence and cell morphological properties (DuRand and Olson, 1996; Rodriguez et al., 1998). Besides cell counting, FCM allows DNA-RNA quantification (Yentsch et al., 1983) per cell, counting of picoplankton and nanoplankton, as well as species or genus-level taxonomical assignments (Blanchot et al., 1997; Grégori et al., 2001). Compared to a conventional FCM, the CytoSense $\left(\right.$ CytoBuoy $\left.^{\circledR}\right)$ pulse-shaped recording scanning flow cytometer (SFCM) provides an in situ and in vivo automated access to phytoplankton dynamics (Dubelaar and Jonker, 2000). It can discriminate between large quantities of cells in a wide size range $(1-800 \mu \mathrm{m})$, based on their optical properties (Dubelaar et al., 1999), including size, shape, and fluorescence derived parameters, through the recording of eachcell's optical profile (Rutten et al., 2005; Thyssen et al., 2008a,b). 
In the present study, the efficiency of the CytoSense for resolving fine spatial phytoplankton variability was tested in coastal and offshore surface waters of the EEC from April 27 to 29, 2012 to relate phytoplankton composition and variability to the water mass distribution and associated physicochemical parameters.

\section{Material and methods}

\subsection{Sampling strategy}

Sampling was conducted continuously during 54 hours, from April 27 to 29, 2012, in the eastern English Channel (EEC) waters (Fig. 1), onboard the 'RV Côtes de la Manche' (CNRS INSU), during the DYPHYMA cruise. The vessel average speed was of about 5 knots. Marine water was pumped from $2 \mathrm{~m}$ depth at 1 bar and brought up to a flow stabilizer chamber continuously at a rate from 200 to $300 \mathrm{~mL}$ per minute. Phytoplankton single cell variables (abundance, fluorescence and size) were recorded every 10 min during 9 min (1 min to stop and flush the system before starting the next analysis). In $9 \mathrm{~min}$, the boat (which travelled at a speed of 5 knots), had crossed $1.5 \mathrm{~km}$. This means that the cytometry data corresponds to a mean abundance covering this distance. Temperature and salinity were recorded every $1 \mathrm{~min}$ by using a "Pocket" Ferry-Box (4H-JENA/GKSS) associated to a Temperature sensor (Pt: 1000) and a salinity sensor (7-conductor cell from Sea\&Sun, Germany).

\subsection{Chlorophyll a, nutrients and turbidity}

Discrete samples were taken with Niskin bottles at 15 stations from $2 \mathrm{~m}$ depth (Fig. 1) to analyse chlorophyll $a$, nutrients as well as for performing microscopic counts. Chlorophyll $a$ (chl a) was estimated by extractive fluorometry (Holm Hansen 1967; Yentsch and Menzel, 1963) using a Turner Designs fluorometer (Model 10-AU). Chl $a$ concentration was measured before and after acidification with $\mathrm{HCl}$, according to Lorenzen (1966). Nutrient samples $\left(\mathrm{NO}_{3}{ }^{-}, \mathrm{PO}_{4}{ }^{3-}, \mathrm{Si}(\mathrm{OH})_{4}\right)$ were taken and directly frozen on board after sampling $(10 \mathrm{ml})$. 
Analysis was performed using the Integral Futura autoanalyser system (Alliance Instruments) with a detection limit of 0.04 and $0.08 \mu \mathrm{mol}$, for $\mathrm{NO}_{3}{ }^{-}$and $\mathrm{PO}_{4}{ }^{3-}$, respectively. CTD (Seabird SBE 25) profiles were also carried out to measure temperature, conductivity, total fluorescence, as well as transmittance, as a proxy of turbidity (C-star transmissometer, Wet labs).

\subsection{Flow cytometry}

Phytoplankton unfixed cells were analysed with the CytoSense Benchtop pulse-shape recording scanning flow cytometer (SFCM, Cytobuoy b.v., Netherlands), with a laser excitation wavelength of $488 \mathrm{~nm}, 20 \mathrm{~mW}$. Single cells were characterized according to their different optical characteristics: sideward angle scatter (SWS), forward scatter (FWS) and red (FLR), orange (FLO) and yellow (FLY) fluorescence. Each cell passes through the laser beam (5 $\mu \mathrm{m}$ width) at a rate of $2 \mathrm{~m} . \mathrm{s}^{-1}$. The CytoSense analyses a wide range of phytoplankton cells (from $1 \mu \mathrm{m}$ to $\sim 800 \mu \mathrm{m})$. Fluorescents beads of $3 \mu \mathrm{m}\left(\right.$ Cyto-Cal $\left.{ }^{\mathrm{TM}}\right)$ and $10 \mu \mathrm{m}\left(\right.$ Polybead $\left.^{\circledR}\right)$ in diameter were used every 12 hours to normalize the SFCM fluorescence and size recording. Data recording was triggered on the red fluorescence signal (i.e. $10 \mathrm{mV}$ ) for 6 to 8 minutes depending on the event rate. Samples were analysed with the Cytoclus ${ }^{\odot}$ software and phytoplankton clusters were manually classified. Clusters were selected by taking into account the amplitude and the shape of the different optical signals. In addition to 5 average signal heights for forward scatter (FWS), sideward scatter (SWS) and for three fluorescence signals: red (FLR), orange (FLO) and yellow (FLY), some simple mathematical parameters were assigned to each signal shape: inertia, fill factor, asymmetry, number of peaks, length, apparent size (FWS; Dubelaar et al., 2004). All these values were plotted into several two dimensional cytograms that facilitated the manual identification of clusters of cells sharing similar optical properties. The area under the red fluorescence curve signal per cell is related to the chlorophyll $a$ fluorescence emission. Within the present study, there was a significant 
correlation between total red fluorescence and chl $a$ concentration $\left(n=15, r^{2}=0.81, p<0.001\right)$.

Total red fluorescence per cluster and per unit of volume (TFLR $\mathrm{cm}^{-3}$ ) was calculated using the red fluorescence curve per cell, and the absolute cluster concentrations given by the SCFCM. TFLR $\mathrm{cm}^{-3}$ was used to estimate the contribution of each cluster to the total fluorescence by summing up the TFLR $\mathrm{cm}^{-3}$ of each cluster. Cell size was estimated using calibration beads according to the following equations:

$($ Correction Factor $)=($ Real beads size $/$ Measured beads size $)(1)$

[Estimated Particles size $(\mu \mathrm{m})]=($ Measured Particles size $*$ Correction Factor $)(2)$

The whole size range of phytoplankton cells was calibrated using beads of $3 \mu \mathrm{m}$ (Cyto-Cal ${ }^{\mathrm{TM}}$ ) and $10 \mu \mathrm{m}\left(\right.$ Polybead $\left.^{\circledR}\right)$.

\subsection{Phytoplankton discrimination by flow cytometry}

Eight clusters (Fig. 2) were determined by SFCM according to the optical properties of cells or particles and attributed to Synechococcus spp, two clusters of picoeukaryotes, Cryptophytes, coccolithophores, microphytoplankton and Phaeocystis globosa haploid and diploid cells. However, SFCM considers particles, which can be single cells as well as colonies, which are mainly represented in the microphytoplankton cluster, and so microphytoplankton cell abundance is underestimated. According to microscopy counting (Gómez and Blondel, unpublished data) performed at some discrete stations (Fig. 1), microphytoplankton was mainly composed of diatoms (98\%), most of them in a colonial form. No significant correlation was found between microphytoplankton FCM and microscopic abundance because FCM is based on particle counts. Therefore, colonies are considered and subsequently counted as one single particle, the same as single cells, whereas microscopic observations refer to cells, whether they be in a colonial or a single cell form. However a significant correlation $\left(\mathrm{p}<0.05 ; \mathrm{r}^{2}=0.70\right)$ was found between $P$. globosa (haploid and diploid) FCM and microscopic counts. 
Diatoms showed the highest FLR and FWS signals because this group comprises large and rich chlorophyll $a$ cells or colonies (Fig. 2A). According to previous SFCM studies in EEC waters and the North Sea (Rutten, 2005; Guiselin, 2010; Houliez et al., 2012), P. globosa haploid and $P$. globosa diploid cells are characterized by lower FLR and FWS signals than those of microphytoplankton cells or colonies (Fig. 2A). P. globosa diploid cells showed higher FLR and FWS signals than $P$. globosa haploid cells. Picoeukaryotes were the smallest eukaryotic cells $(<2 \mu \mathrm{m})$ and as a consequence they also showed low FLR and FWS signals (Fig. 2A). Picoeukaryotes I and picoeukaryotes II were differentiated from each other based on the amplitude of their red fluorescence signal, which was assumed to be due to more chlorophyll $a$ content in picoeukaryotes II than in picoeukaryotes I. Picoeukaryotes II were also less fluorescent and smaller than P. globosa haploid and P. globosa diploid cells. Coccolithophores (Fig. 2B) were well characterised by flow cytometry since, although they have the same FLR and FWS signals as P. globosa haploid and diploid cells, their SWS signal is higher due to their $\mathrm{CaCO}_{3}$ platelet coverings (Olson et al., 1989). The Synechococcus spp cluster showed a characteristic signature with low FWS because its the very small size and a peak in orange fluorescence (FLO) caused by its high content of phycoerythrine (Fig. 2B). Cryptophytes were large cells and contained high amounts of phycoerythrine per cell (Olson et al., 1989), which produced higher FLO and FWS signals than those of Synechococcus spp (Fig. 2B).

\subsection{Statistical analysis}

The water mass discrimination was carried out based on the temperature and salinity data and using a T/S diagram. Phytoplankton data from different samples were compared using the Plymouth routines in multivariate ecological research (PRIMER v.6) software package (Clarke and Gorley, 2006). The Bray-Curtis dissimilarity index was applied to test the 
similarities between stations and define phytoplankton communities using the Ward method, which consists in aggregating two clusters so that the increment of within-inertia is minimised at each step of the algorithm. The within-inertia defines the homogeneity of a cluster (Husson et al., 2010). The package FactoMineR (Lê et al., 2008) with software R.2.11.1 was used to apply the Ward method. An analysis of similarities (one-ways ANOSIM) was used to test the significance of differences between phytoplankton communities.

\section{Results}

\subsection{Hydrological parameters}

The ship track was superimposed on the map of temperature (Fig. 3A) and salinity (Fig. 3B). Relatively low fresh water inflow characterised the English EEC coast, whereas the influence of local or remote estuaries indicated on the figure 1 (the Seine $\left(563 \mathrm{~m}^{3} \mathrm{~s}^{-1}\right)$, the Somme (35 $\left.\mathrm{m}^{3} \mathrm{~s}^{-1}\right)$, the Authie $\left(10 \mathrm{~m}^{3} / \mathrm{s}\right)$ and the Canche $\left(11 \mathrm{~m}^{3} \mathrm{~s}^{-1}\right)$, in annual daily flow average) was evidenced in the French Coast of EEC and could explain the difference in salinity and temperature observed between the French and English coastal waters. While the highest values of salinity were measured in English coastal waters and in mid-Channel waters with a maximum of 35.30 , the lowest values of salinity were located in French coastal waters (i.e. 34.08). The lowest temperatures were measured in English offshore waters with a minimum of $9.41{ }^{\circ} \mathrm{C}$ off Dover while the highest temperatures were measured in coastal waters with a maximum of $10.42^{\circ} \mathrm{C}$, close to Eastbourne (Fig. 3B). The cruise track crossed three water masses labelled W1, W2 and W3 defined on the basis of their temperature and salinity features (T/S diagram not shown). Their average hydrological values and nutrient contents are reported in Table 1 and their location is represented in Figure $3 \mathrm{C} . \mathrm{NO}_{3}{ }^{-}$concentration varied from the detection limit up to $3.83 \mu \mathrm{mol} \mathrm{L}-1$. $\mathrm{PO}_{4}{ }^{3-}$ values varied from the detection limit and $0.65 \mu \mathrm{mol} \mathrm{L}{ }^{-1}$. The highest concentrations in $\mathrm{NO}_{3}{ }^{-}$and $\mathrm{PO}_{4}{ }^{3-}$ were observed in $\mathrm{W} 3$, off Eastbourne. The Redfield $\mathrm{NO}_{3}{ }^{-} / \mathrm{PO}_{4}{ }^{3-}$ ratio (Redfield et al., 1963) values varied between 0.25 
and 30. All values were $<16$ during the cruise except between Lydd and Eastbourne within W3 where it reached values of 30 . Unfortunately, $\mathrm{Si}(\mathrm{OH})_{4}$ analyses were discarded due to analytical problems. The highest values of attenuation of light (transmittance) were obtained in W2 and the lowest values in W1 (table 1).

\subsection{Phytoplankton abundance and total red fluorescence}

An important spatial heterogeneity in phytoplankton distribution was observed all along the sampling area (Fig. 4A). The effect of the time of the day during sampling, which was tested by ANOSIM, was found not significant (p>0.05). P. globosa haploid and diploid cells were the most concentrated groups in most $\mathrm{W} 1$ and in W2 waters, ranging between approx. $25 \mathrm{x}$ $10^{2}$ and $33 \times 10^{3}$ cells $\mathrm{mL}^{-1}$. Picoeukaryotes I and Synechococcus spp were the most abundant phytoplankton groups in W3 waters with average values of $62 \times 10^{2} \pm 49 \times 10^{2}$ cells $\mathrm{mL}^{-1}$ for picoeukaryotes I and $34 \times 10^{2} \pm 31 \times 10^{2}$ cells $\mathrm{mL}^{-1}$ for Synechococcus spp. W3 was also characterized by the occurrence of other groups such as coccolithophores $(243 \pm 140$ cells $\left.\mathrm{mL}^{-1}\right)$ and Cryptophytes $\left(130 \pm 80\right.$ cells $\left.\mathrm{mL}^{-1}\right)$. Picoeukaryotes II and diatoms were more abundant in W1 and in W2 waters than in W3 waters, with an average abundance of about 1300 cells $\mathrm{mL}^{-1}$ and 150 cells $\mathrm{mL}^{-1}$ respectively.

The continuous recording by SFCM (Fig.4A) revealed a sharp change in composition and in abundance at low spatial scale. In fact, two main peaks of total phytoplankton cell numbers were detected in W3 waters, one near the English coast $\left(25 \times 10^{3}\right.$ cells $\mathrm{mL}^{-1}, \sim 120 \mathrm{~km}$ from the starting point) and one in mid EEC waters $\left(35 \times 10^{3}\right.$ cells $\mathrm{mL}^{-1}, \sim 150 \mathrm{~km}$ from starting point). High total phytoplankton cell numbers were also recorded in W2 with values of $33 \mathrm{x}$ $10^{3}$ cells $\mathrm{mL}^{-1}$ near the Canche estuary $(295 \mathrm{~km}$ from the starting point) as well at the transition between $\mathrm{W} 1$ with $\mathrm{W} 3\left(40 \times 10^{3}\right.$ cells $\mathrm{mL}^{-1}, \sim 25 \mathrm{~km}$ from starting point). These abundance peaks were mainly composed by picoeukaryotes I and Synechococcus spp, except 
at $120 \mathrm{~km}$ from the start, where $P$. globosa haploid cells were more abundant than Synechococcus spp and at $295 \mathrm{~km}$ where $P$. globosa haploid was the dominant group.

The highest values in total red fluorescence, used as a proxy for phytoplankton chlorophyll $a$ content, were observed in W1 and W2 waters (Fig. 4B), with a maximum of $7 \times 10^{5}$ a.u. $\mathrm{mL}^{-1}$ by $240 \mathrm{~km}$ from the start, and high values off the Canche estuary $\left(>6 \times 10^{5}\right.$ a.u. $\left.\mathrm{mL}^{-1}\right) . P$. globosa diploid cells and diatoms were responsible for most of the total red fluorescence (Fig. 4B) in all three water masses (W1, W2 and W3), except in mid-Channel waters (150 km from the start) where picoeukaryotes I, coccolithophores, Cryptophytes and Synechococcus spp represented up to $50 \%$ of the total red fluorescence. Except for some areas (e.g. 120-140 km, where P. globosa diploid fluorescence was high in spite of their cell abundance), W3 waters were characterised by the lowest total red fluorescence values (lower than $10^{5}$ a.u. $\mathrm{mL}^{-1}$ ).

\subsection{Phytoplankton community structure}

The distribution of phytoplankton clusters was not necessarily compliant with that of the three identified water masses. As a result of the Bray-Curtis matrix coupled to Ward's classification method applied to the whole continuous-recorded phytoplankton abundance dataset, 4 phytoplankton communities were identified during the transect $(\mathrm{p}<0.05$; Fig. 5). Communities CM1 and CM2 were mainly located in French coastal and offshore waters as well as off Eastbourne (CM1). CM3 was located in EEC offshore waters. CM4 characterised mainly the English coastal waters of the EEC, as well as offshore French waters by the Strait of Dover. Except in French coastal waters under direct estuarine influence, the transition between communities was sometimes sharp in relatively short distances, as measured in French coastal waters near the Strait of Dover with all communities describe on a short spatial scale: CM2 in coastal waters, CM4 in offshore waters and CM3 in mid-Channel waters. The patchy distribution of phytoplankton communities was also represented, off Eastbourne, 
where CM1, CM4 and CM3 alternated within a few kilometres, showing no evident correlation with the physicochemical parameters measured.

Phytoplankton communities CM1 and CM2 were characterised (Fig. 6) by high abundance of Phaeocystis globosa (58\% and $79 \%$ of the total abundance, respectively, with the dominance of haploid cells). Picoeukaryotes II and diatoms (to a lesser extent) were more represented in CM2 than in CM1 (Fig. 6). CM3 was characterised by a high contribution of picoeukayotes I (53\%) and Synechococcus spp (36\%). CM4 was also characterised by picoeukayotes I (49\%) but with less Synechococcus spp and more haploid (10\%) and diploid P. globosa cells (15\%) than in CM3.

Diatoms, together with $P$. globosa haploid and diploid cells contributed to most of the total red fluorescence (Fig. 4B). Their highest values were observed in CM2 and CM1 (Table 2) confirming the contribution of diatoms and P. globosa haploid and diploid clusters to the total chlorophyll concentration. Within CM3, which was characterised by the lowest total red fluorescence, Synechococcus spp, Cryptophytes, picoeukaryotes I and coccolithophores reached their highest red fluorescence values (Table 2).

Red fluorescence per cell, normalized by cell size, was also calculated (Tables 3 ). The aim of normalization was to avoid a size effect. The highest values of normalized red fluorescence per cell were not necessarily measured in the clusters representing the highest total red fluorescence. CM3 showed the highest values of red fluorescence per cell measured in most of the phytoplankton groups (except for P. globosa haploid and diploid cells). For picoeukaryotes I, picoeukaryotes II, Synechococcus spp and diatoms cells, the lowest values of red fluorescence per cell were measured within the CM2, exclusively in coastal French 
waters directly influenced by estuarine inputs. On the contrary, P. globosa haploid and diploid cells reached their highest values of normalized red fluorescence within the CM2, which also represented maximum abundance.

\section{Discussion}

\subsection{Water masses and physicochemical conditions}

In the present study, three waters masses were defined in the EEC waters along the 315 kilometres explored within the DYPHYMA cruise, based on salinity and temperature. High salinity values were observed within water mass W3 (Fig.3), which should correspond to Atlantic waters which are channelled towards the North Sea (Quisthoudt et al., 1987a), as was also stated by Salomon and Breton (1993) and Guegueniat et al (1995). French EEC coastal waters (W1 and W2) can be defined as a coastal ecosystem receiving large freshwater inputs from local and remote rivers. The physical parameters observed during the cruise were in line with previous studies in the eastern and central English Channel at this time of the year (Brylinski et al., 1991; Napoléon et al., 2012; Houliez et al., 2013). French EEC coastal waters, named 'coastal flow' (Brylinski et al., 1991) receive river inputs along the coast from the Bay of the Seine up to the Cape Gris-Nez (Strait of Dover). The 'coastal flow' is rich in suspended matter and macronutrients mainly brought locally by the Somme, the Authie and the Canche rivers. In fact, the lowest values of transmittance were found in this area, while the highest values were located in the mid-Channel and in English coastal waters. In order to complete our understanding of nutrient conditions during the period of our cruise, considering that $\mathrm{NH}_{4}+$ could not be measured and DSi concentrations were discarded because of analytical problems, nutrient values were retrieved from local coastal monitoring programs. The sites off the Somme estuary and Boulogne sur Mer (Regional Nutrients Monitoring Network, SRN; Nzigou and Lefebvre, 2013) were sampled a week before and after the cruise. DIN, DIP and DSi concentrations from SRN were, in both sites, $\leq 1.2, \leq 0.22$ and $\leq 1.74$ 
$\mu \mathrm{mol} \mathrm{L} \mathrm{L}^{-1}$, respectively. All nutrient concentrations retrieved from local monitoring networks were in the same range than DIN and DIP measured during our cruise. According to Lefebvre et al (2011) in winter conditions, DIN, DIP and DSi values usually range from 15 to 50, 3 to 4 and 10 to $4 \mu \mathrm{mol} \mathrm{L}{ }^{-1}$, respectively, then decreasing during the rest of the year. The nutrients conditions measured during the cruise are typically associated with the end of a spring bloom in EEC waters (Brunet et al, 1992; Lancelot, 1995; Grattepanche et al. 2011a,b; Lefebvre et al., 2011; Napoléon et al., 2012).

\subsection{Phytoplankton spatial distribution}

Sharp shifts in phytoplankton abundance were observed at the sub mesoscale $(1-10 \mathrm{~km})$. The direct influence of the Somme ( $260 \mathrm{~km}$ from start) and the Canche (295 km from start) estuaries was marked by an increase in phytoplankton abundance and total red fluorescence (Fig. 5). In fact, phytoplankton benefited from direct nutrient inputs from local rivers (the lowest salinities of the cruise were measured in the area). In the coastal French EEC waters, the community was mainly composed of nanophytoplankton as P. globosa (CM1 and CM2), whereas in English and mid Channel waters, small-cells as picoeukaryotes and Synechococcus spp (CM3 and CM4) where dominant in terms of abundance. Temperature and salinity continuously measured during the cruise could not explain alone the transitions between the different community structures.

Previous studies at low frequency in French EEC coastal waters (Breton et al., 2000; Gómez and Souissi 2007; Schapira et al., 2008; Lefebvre et al., 2011; Grattepanche et al. 2011a,b; Hernández-Fariñas et al., 2013) indicate the dominance of $P$. globosa and diatoms in terms of abundance and biomass from late winter to mid-late spring. Within the first leg of the DYPHYMA cruise (April 20, 2012; data not shown) an abundance of $P$. globosa diploid cells of $20 \times 10^{3}$ cells $\mathrm{mL}^{-1}$ and $P$. globosa haploid cells of $9 \times 10^{3}$ cells $\mathrm{mL}^{-1}$ were counted by 
SFCM in French coastal waters. One week later (the present study), P. globosa diploid cell abundance (in the same areas and at the same scale) had dropped to approximately $6 \times 10^{3}$ cells $\mathrm{mL}^{-1}$ while $P$. globosa haploid cells increased up to $25 \times 10^{3}$ cells $\mathrm{mL}^{-1}$. This change in dominance between the two life-forms of $P$. globosa coupled to the low nutrient concentrations measured in EEC waters within both cruises indicate, in agreement with previous studies (Rousseau et al., 1994; Peperzak et al., 2000; Rousseau et al., 2007; Guiselin, 2010), the end of a spring bloom, at least in the French coastal EEC waters (characterized by both CM1 and CM2).

\subsection{Water mass characterisation based on phytoplankton community structure}

In reference to Cebrián and Valiela's classification (1999), the waters characterised by a high phytoplankton biomass peak in spring or in summer due to high nutrient concentrations, as in

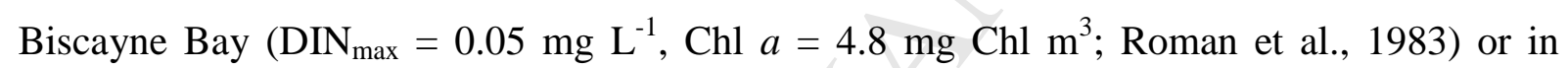

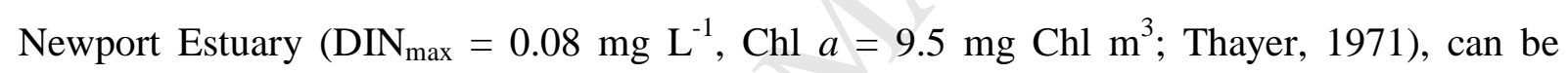
defined as an Enclosed Coastal Ecosystem (ECE), whereas the waters characterised by a high phytoplankton biomass peak in winter or fall as in Banyuls coast (Ibarra, 1981) could be considered as an Open Coastal Ecosystem (OCE).

Considering nutrient, chlorophyll $a$ and phytoplankton concentrations reported in the area by previous seasonal and inter-annual studies (Gómez \& Souissi 2007; Lefebvre et al., 2011; Hernández-Fariñas et al., 2013), as well as the red fluorescence dynamics and chlorophyll $a$ concentrations described in the present study, French EEC coastal waters under direct estuarine influence can indeed be defined as an Enclosed Coastal Ecosystem (ECE), whereas English as well as mid-Channel waters, could be considered as an Open Coastal Ecosystem (OCE). In the English coastal waters of the central English Channel (off Porstmouth), previously investigated during a seasonal cycle by Napoléon et al. (2012), the phytoplankton 
biomass reached its peak between November and March, earlier than when observed in French coastal waters (Guiselin, 2010; Houliez et al., 2013). In the event that CM1 and CM2 characterised an ending bloom stage within an ECE during our DYPHYMA cruise, then CM3 and CM4 would have mainly characterised a more advanced post-bloom stage within an OCE, with a phytoplankton community structure mainly composed of small cells. Different stages of the spring blooms are often dominated by phytoplankton of different sizes. The traditional view is that post-bloom periods are dominated by small cells like picoplankton (Riegman et al., 1993; Kiorboe, 1993). Indeed, small algae are better competitors than larger species when the nutrient concentration is low (Smith and Kalff, 1982; Grover, 1989; Riegman et al., 1993), confirming that most Eastern English Channel waters are favourable to the occurrence and predominance of small phytoplankton species at this specific time of the year.

\subsection{The single-cell features variability}

The single-cell features within each phytoplankton group, such as fluorescence per cell, can provide information about the physiological state of cells (Olson et al, 2000; Thyssen et al., 2008a, 2009). Within the CM2 community structure (characterizing exclusively ECE in French coastal waters), $P$. globosa haploid and diploid cells showed the highest values of red fluorescence (table. 3) while the lowest values were measured in CM3 and CM4 (characterizing OCE). As red fluorescence can be considered as a proxy of chlorophyll $a$ content, then the P. globosa cellular chlorophyll $a$ content is probably higher in more turbid waters. The impact of turbidity has been abundantly described for phytoplankton (Behrenfeld et al., 2004; Cloern, 1987; Quisthoudt, 1987b). To compensate for reduced light due to high suspended matter concentration in coastal waters, phytoplankton cells tend to increase their pigment content (MacIntyre et al., 2000; Moore et al., 2006). The P. globosa development is limited by light availability in French coastal waters under estuarine influence (characterised 
by CM2) in comparison with offshore and mid-Channel waters (mainly characterised by CM3 and CM4). However, the good photoacclimation of $P$. globosa cells at low light could explain their maintenance in this area.

\section{Conclusion}

The use of scanning flow cytometry as a high frequency continuous recording system made it possible to draw a synoptic picture of phytoplankton composition and distribution, at a single-cell level and high spatial resolution, in the eastern English Channel. Moreover, the device used in this study, which is designed for phytoplankton analysis, offered the possibility for real time monitoring of the in situcell size and fluorescence from pico- to microphytoplantkon. Size classes and functional groups were characterised and gathered into four community structures which were not always ascribed to single water masses. In addition, phytoplankton taxonomic and functional diversity needs the most accurate and objective discrimination and classification of cytometric data to avoid misinterpretations as well as incomplete analysis and identification of clusters, which could be prevented by using a combination of semi-automated classification tools (Caillault et al., 2009; Malkassian et al., 2011). Finally, the accurate assessment of phytoplankton dynamics at sub-mesoscale depends on the possibility of addressing physicochemical, hydrological as well as physiological features at high frequency too.

\section{Acknowledgements}

We thank the captain and the crew of the RV "Côtes de la Manche" (INSU-CNRS) for their help during the cruise. Vincent Cornille and Marine Verne are acknowledged for their technical assistance during the sampling and water filtration for chlorophyll $a$ analyses, Eric Lécuyer for treatment of CTD data. We thank Morgane Didry and Marine Verne for chlorophyll $a$ analyses and Valérie Gentilhomme for laboratory measurements of nutrient concentrations. Acknowledgments are due to Fernando Gómez and Camille Blondel for 
providing us with their microscopic counts, as well as to Mathias Broutin for his help drawing the maps. We thank the two anonymous reviewers for their comments and suggestions for improving the original version of the ms, as well as Dr. Luff for English correction. This study was part of the DYPHYMA cruise (2nd leg) supported by the DYMAPHY (INTERREG IVA “2 Mers Seas Zeeën”) project (www.dymaphy.eu) co-funded by the European Regional Development Funds (ERDF). S. Bonato is supported by a Ph.D. grant cofunded by the DYMAPHY project and the "Syndicat Mixte de la Côte d'Opale" (SMCO).

\section{References}

Agawin, N.S., Duarte, C.M., Agusti, S., 2000. Nutrient and temperature control of the contribution of picoplankton to phytoplankton biomass and production. Limnol. Ocean., 45, 591-600.

Ahel, M., Barlow, R.G., Mantoura, R.F.C., 1996.Effect of salinity gradients on the distribution of phytoplankton pigments in a stratified estuary.Mar. Ecol. Prog. Ser., 143, 289-295.

Behrenfeld, M.J., Prasil, O., Babin, M., Bruyant, F., 2004. In search of physiological basis for covariations in light-limited and light-satured photosynthesis. Journal of phycology., 40, 4-25.

Blanchot, J., André, J.-M., Navarette, C., Neveux, J., 1997.Picophytoplankton dynamics in the equatorial Pacific: diel cycling from flow-cytometer observations. Comptes Rendus Académie Sci. - Ser. III - Sci. Vie, 320, 925-931.

Breton, E., Brunet, C., Sautour, B., Brylinski, J.-M., 2000. Annual variations of phytoplankton biomass in the Eastern English Channel: comparison by pigment signatures and microscopic counts. J. Plankton Res., 22, 1423-1440.

Brunet, C., Brylinski, J.M., Frontier, S., 1992. Productivity photosynthetic pigments and hydrology in the coastal front of the Eastern English Channel. J. Plankton Res., 14, 1541-1552.

Brunet, C., Brylinski, J.M., Bodineau, L., Thoumelin, G., Bentley, D., Hilde, D., 1996. Phytoplankton Dynamics During the Spring Bloom in the South-eastern English Channel. Estuar. Coast. Shelf Sci., 43, 469-483.

Brylinski, J.M., 1991. Le "fleuve cotier" : un phenomene hydrologique important en Manche orientale (exemple du Pas-de-Calais). Ocean. Acta, 11, 197-203.

Caillault É., Hébert P.-A., Wacquet G. (2009). Dissimilarity-based classification of multidimensional signals by conjoint elastic matching: application to phytoplanktonic species recognition, in Engineering Applications of Neural Networks, eds Palmer Brown D., Draganova C., Pimenidis E., Mouratidis H., editors. (Berlin; Heidelberg: Springer), 153-164.

Cassie, R.M., 1963. Microdistribution of plankton. Ocean. Mar. Biol. Annu. Rev. H.Barnes (Eds.). 1: 223-252.

Cebrián, J., Valiela, I., 1999. Seasonal patterns in phytoplankton biomass in coastal ecosystems. J. Plankton Res., 21, 429-442.

Christaki U., Kormas KA., Genitsaris S., Georges C., Sime-Ngando T., Viscogliosi E., 
Monchy S., 2014. Winter-summer succession of unicellular eukaryotes in mesoeutrophic coastal system. Microb. Ecol. 67:13-23, DOI: 10.1007/s00248-013-0290

Clarke K.R., Gorley R.N., 2006. PRIMER v6: User Manual/Tutorial. PRIMER-E, Plymouth.

Cloern, J.E., 1996. Phytoplankton bloom dynamics in coastal ecosystems: A review with some general lessons from sustained investigation of San Francisco Bay, California. Rev. Geophys., 34(2), 127-168.

Cloern, J.E., 1987. Turbidity as a control on phytoplankton biomass and productivity in estuaries. Cont. Shelf Res. 7, 1367-1381.

Dubelaar, G.B.J., Gerritzen, P.L., Beeker, A.E.R., Jonker, R.R., Tangen, K., 1999. Design and first results of CytoBuoy: A wireless flow cytometer for in situ analysis of marine and fresh waters. Cytometry, 37, 247-254.

Dubelaar, G.B.J., Jonker, R.R., 2000. Flow cytometry as a tool for the study of phytoplankton. Sci. Mar., 64, 135-156.

Dubelaar, G.B.J., Geerders, P.J.F., Jonker, R.R., 2004. High frequency monitoring reveals phytoplankton dynamics. J. Environ. Monit., 6, 946-952.

DuRand, M.D., Olson, R.J., 1996. Contributions of phytoplankton light scattering and cell concentration changes to diel variations in beam attenuation in the equatorial Pacific from flow cytometric measurements of pico-, ultra- and nanoplankton. Deep-Sea Research II., 43. 891-906.

Falkowski, P.G., Dubinsky, Z., Wyman, K., 1985. Growth-irradiance relationships in phytoplankton. Limnol.Ocean., 30, 311-321.

Gómez, F., Souissi, S., 2007.Unusual diatoms linked to climatic events in the northeastern English Channel. J. Sea Res. 58, 283-290.

Grattepanche, J.-D., Breton, E., Brylinski, J.-M., Lecuyer, E., Christaki, U., 2011a. Succession of primary producers and micrograzers in a coastal ecosystem dominated by Phaeocystis globosa blooms. J. Plankton Res., 33, 37-50.

Grattepanche, J.-D., Vincent, D., Breton, E., Christaki, U., 2011b. Microzooplankton herbivory during the diatom-Phaeocystis spring succession in the eastern English Channel. J. Exp. Mar. Biol. Ecol. 404, 87-97.

Grégori, G., Colosimo, A., Denis, M., 2001. Phytoplankton group dynamics in the Bay of Marseilles during a 2-year survey based on analytical flow cytometry. Cytometry, 44, 247-256.

Grover, J.P., 1989. Influence of cell shape and size on algal competitive ability. Journal of phycology., 25, 402-405.

Guegueniat, P., du Bois, P.B., Salomon, J.C., Masson, M., Cabioch, L., 1995. FLUXMANCHE radiotracers measurements: A contribution to the dynamics of the English Channel and North Sea. J. Mar. Syst., 6, 483-494.

Guiselin, N., 2010. Caractérisation des évènements phytoplanctoniques en zone côtière : test des techniques alternative et développement d'indicateurs de qualité des masses d'eau. $\mathrm{PhD}$ Thesis in Biological Oceanography. Université du Littoral Côte d'Opale, France. 183 pp.

Hernández-Fariñas, T., Soudant, D., Barillé, L., Belin, C., Lefebvre, A., Bacher, C., 2013. Temporal changes in the phytoplankton community along the French coast of the eastern English Channel and the southern Bight of the North Sea. doi:10.1093/icesjms/fst192.

Houliez, E., Lizon, F., Thyssen, M., Artigas, L.F., Schmitt, F.G., 2012. Spectral fluorometric characterization of Haptophyte dynamics using the FluoroProbe: an application in the eastern English Channel for monitoring Phaeocystisglobosa. J. Plankton Res., 34, $136-151$. 
Houliez, E., Lizon, F., Artigas, L.F., Lefebvre, S., Schmitt, F.G., 2013. Spatio-temporal variability of phytoplankton photosynthetic activity in a macrotidal ecosystem (the Strait of Dover, eastern English Channel). Estuar.Coast. Shelf Sci., 129, 37-48.

Husson, F., Josse, J., Pages, J., 2010. Principal component methods - hierarchical clustering partitional clustering: why would we need to choose for visualizing data? Technical Report Agrocampus.

Jacquet, S., Prieur, L., Avois-Jacquet, C., Lennon, J.-F., Vaulot, D., 2002. Short-timescale variability of picophytoplankton abundance and cellular parameters in surface waters of the Alboran Sea (western Mediterranean). J. Plankton Res. 24, 635-651.

Kiorbe, T. 1993. Turbulence, phytoplankton cell size, and structure of pelagic food webs. Advance in Marine Biology 29 : 1-72.

Lancelot, C., 1995. The mucilage phenomenon in the continental coastal waters of the North Sea. Sci. Total Environ., 165, 83-102.

Lê, S., Josse, J., Husson, F., 2008. FactoMineR: An R package for multivariate analysis. J. Stat. Softw., 25, 1-18.

Lefebvre, A., Guiselin, N., Barbet, F., Artigas, F.L., 2011.Long-term hydrological and phytoplankton monitoring (1992-2007) of three potentially eutrophic systems in the eastern English Channel and the Southern Bight of the North Sea. ICES J. Mar. Sci., 68, 2029-2043.

Lorenzen, C.J., 1966. A method for the continuous measurement of in vivo chlorophyll concentration.Deep Sea Res. Ocean.Abstr., 13, 223-227.

MacIntyre, H.L., Kana, T.M., Geider, R.J., 2000. The effect of water motion on short-term rates of photosynthesis by marine phytoplankton.Trends Plant Sci. 5, 12-17.

Malkassian, A., Nerini, D., van Dijk, M. A., Thyssen, M., Mante, C., and Gregori, G. (2011). Functional analysis and classification of phytoplankton based on data from an automated flow cytometer. Cytometry A. 79, 263-275. doi: 10.1002/cyto.a.21035.

Margalef, R., Estrada, M., Blasco, D., 1979. Functional morphology of organisms involved in red tides, as adapted to decaying turbulence. In: Taylor, D.L., Seliger, H.H. (Eds.), Toxic Dinoflagellate Blooms. Elsevier/North-Holland, New York, pp. 89-94.

Martin, A.P., Zubkov, M.V., Burkill, P.H., Holland, R.J., 2005. Extreme spatial variability in marine picoplankton and its consequences for interpreting Eulerian time-series. Biol. Lett. 1, 366-369.

Monchy S., Grattepanche J-D., Breton E., Dionigia M., Sanciu G., Chabé M., Delhaes L., Viscogliosi E., Sime-Ngando T., Christaki U., 2012. Microplanktonic Community Structure in a Coastal System Relative to a Phaeocystis Bloom Inferred from Morphological and Tag Pyrosequensing Methods. Plos ONE 7(6):e39924. Doi:10.1371/journal.pone.0039924.

Moore, Cm.,Suggett, D.J., Hickman, A.E., Kim, Y.-N., Tweddle, J.F., Sharples, J., Geider, R.J., Holligan, P.M., 2006. Phytoplankton photoacclimation and photoadaptation in response to environmental gradients in a shelf sea.Limnol. Ocean., 51, 936-949.

Napoléon, C., Raimbault, V., Fiant, L., Riou, P., Lefebvre, S., Lampert, L., Claquin, P., 2012. Spatiotemporal dynamics of physicochemical and photosynthetic parameters in the central English Channel.J. SeaRes., 69, 43-52.

Niraula, M.P., Casareto, B.E., Lan Smith, S., Hanai, T., Suzuki, Y., 2007. Examining the effects of nutrients on the composition and size of phytoplankton using unaltered deep-sea waters. J. Exp. Mar. Biol. Ecol., 348, 23-32.

Nzigou, A-R, Lefebvre, A., 2013. The regional nutrients monitoring network of the coastal zone of the Nord Pas-de-Calais Picardie Region. Annual report for 2012. 
Olson, R.J., Sosik, H.M., Chekalyuk, A.M., Shalapyonok, A., 2000. Effects of iron enrichment on phytoplankton in the Southern Ocean during late summer: active fluorescence and flow cytometric analyses. Deep-Sea Research II., 47,3181-3200.

Olson, R.J., Zettler, E.R., Anderson, O.K., 1989. Discrimination of eukaryotic phytoplankton cell types from light scatter and autofluorescence properties measured by flow cytometry. Cytometry 10, 636-643.

Peperzak, L., Colijn, F., Vrieling, E.G., Gieskes, W.W.C., Peeters, J.C.H., 2000. Observations of flagellates in colonies of Phaeocystis globosa (Prymnesiophyceae); a hypothesis for their position in the life cycle. J. Plankton Res. 22, 2181-2203.

Quisthoudt, C., Bentley, D., Brylinski, J.M., 1987a. Discontinuité hydrobiologique dans le détroit du Pas-de-Calais. J. Plankton Res., 9, 995-1002.

Quisthoudt, C., 1987b. Production primaire phytoplanctonique dans le détroit du Pays-deCalais (France): variations spatiales et annuelles au large du Cap Gris-Nez. Comptes Rendus Académie Sci. Série 3 Sci. Vie, 304, 245-250.

Redfield, A.C., Ketchum, B.H., Richards, F.A., 1963. The influence of organisms on the composition of sea water, in: The Sea, M.N. Hill, ed., vol.2, Wiley (Interscience), New York, pp. 26-27.

Riegman, R., Kuipers, B.R., Noordeloos, A.A.M., Witte, H.J., 1993. Size-differential control of phytoplankton and the structure of plankton communities. Neth. J. Sea Res., 31, $255-265$.

Rodríguez, J., Blanco, J.M., Jiménez-Gómez, F., Echevarría, F., Gil, J., Rodríguez, V., Ruiz, J., Bautista, B., Guerrero, F., 1998. Patterns in the size structure of the phytoplankton community in the deep fluorescence maximum of the Alboran Sea (southwestern Mediterranean). Deep-Sea Res. Part, 45, 1577-1593.

Rousseau, V., Chrétiennot-Dinct, M.-J., Jacobsen, A. Verity, P., Whipple, S., 2007. The life cycle of Phaeocystis: state of knowledge and presumptive role in ecology. Biogeochemistry 83, 29-47.

Rousseau, V., Vaulot, D., Casotti, R., Cariou, V., Lenz, J., Junkel, J., Baumann, M., 1994. The life cycle of Phaeocystis (Prymnesiophyceae): evidence and hypothesis. In:

Lancelot, C., Wassmann, P. (Eds.), Ecology of Phaeocystis-dominated Ecosystems. J. Mar. Syst. 5, 23-39.

Rutten, T.P.A., Sandee, B., Hofman, A.R.T., 2005. Phytoplankton monitoring by high performance flow cytometry: A successful approach? Cytometry Part A, 64A, 16-26.

Sazhin, A.F., Artigas, L.F., Nejstgaard, J.C., Frischer, M.E., 2007. The colonization of two Phaeocystis species (Prymnesiophyceae) by pennate diatoms and other protists: a significant contribution to colony biomass. Biogeochemistry, 83, 137-145.

Salomon, J.-C., Breton, M., 1993. An atlas of long-term currents in the Channel.Ocean.Acta, $16,439-448$.

Sautour, B., Artigas, L.F., Delmas, D., Herbland, A., Laborde, P., 2000. Grazing impact of micro- and mesozooplankton during a spring situation in coastal waters off the Gironde estuary. J. Plankton Res. 22, 531-552.

Schapira, M., Vincent, D., Gentilhomme, V., Seuront, L., 2008. Temporal patterns of phytoplankton assemblages, size spectra and diversity during the wane of a Phaeocystis globosa spring bloom in hydrologically contrasted coastal waters. J. Mar. Biol. Assoc. United Kingd., 88, 649-662.

Smayda, T.J., Reynolds, C.S., 2001. Community Assembly in Marine Phytoplankton: Application of Recent Models to Harmful Dinoflagellate Blooms. J. Plankton Res. 23, 447-461.

Smith, R.E.H., Kalff, J., 1982. Size-dependant phosphorus uptake kinetics and cell quota in phytoplankton. Journal of phycology., 18, 275-284. 
Sosik, H.M., Olson, R.J., Neubert, M.G., Shalapyonok, A., 2003. Growth rates of coastal phytoplankton from time-series measurements with a submersible flow cytometer. Limnol. Ocean., 48(5), 2003, 1756-1765.

Suttle, C.A., Chan, A.M., Cottrell, M.T., 1990. Infection of phytoplankton by viruses and reduction of primary productivity. Nature., 347, 467-469.

Thyssen, M., Mathieu, D., Garcia, N., Denis, M., 2008a. Short-term variation of phytoplankton assemblages in Mediterranean coastal waters recorded with an automated submerged flow cytometer. J. Plankton Res., 30, 1027-1040.

Thyssen, M., Tarran, G.A., Zubkov, M.V., Holland, R.J., Grégori, G., Burkill, P.H., Denis, M., 2008b. The emergence of automated high-frequency flow cytometry: revealing temporal and spatial phytoplankton variability. J. Plankton Res., 30, 333-343.

Thyssen, M., Garcia, N., Denis, M., 2009. Sub meso scale phytoplankton distribution in the North East Atlantic surface waters determined with an automated flow cytometer. Biogeosciences 6, 569-583.

Veldhuis, M.J.W., Kraay, G.W., 2000. Application of flow cytometry in marine phytoplankton research: current applications and future perspectives. Sci. Mar., 64, 121-134.

Yentsch, C.M., Horan, P.K., Muirhead, K., Dortch, Q., Haugen, E., Legendre, L., Murphy, L.S., Perry, M.J., Phinney, D.A., Pomponi, S.A., 1983. Flow cytometry and cell sorting: A technique for analysis and sorting of aquatic particles. Limnol.Ocean., 28, 1275-1280.

Yentsch, C.S., Menzel, D.W., 1963. A method for the determination of phytoplankton chlorophyll and phaeophytin by fluorescence. Deep Sea Res. Ocean.Abstr., 10, 221231 . 
Table 1. Average values of transmittance, salinity, temperature and nutrients for each water nmass defined by temperature and salinity data.

Table 2. Average red fluorescence (a.u. $\mathrm{mL}^{-1}$ ), with its standard deviation, for each phytoplankton cluster, within each community structure (CM). The letters in superscript indicate their ranking values.

Table 3. Average red fluorescence per cell (a.u.) normalized by its size (with its standard deviation) for each phytoplankton group, within each community structure (CM). The letters in superscript indicate its ranking value.

Fig 1. Study area and location of the sampling stations, in the eastern English Channel (EEC) during the DYMPHYMA cruise, from April 27 to 29, 2012. The ship sailed 315 km from "Start" to "End", anticlockwise. The grey circled dots correspond to nutrients, chlorophyll $a$ and phytoplankton counts sampling stations. The grey arrows indicate the main current direction according to the tide conditions.

Fig 2. SFCM (CytoSense) cytograms and clusters defined in the EEC during the DYPHYMA cruise. A. Red fluorescence area per cell (a.u.) vs FWS length per cell (a.u.) cytogram, in which picoeukaryotes I and II, Phaeocystis globosa haploid/diploid and diatoms are discriminated. B. Orange fluorescence area per cell (a.u.) vs SWS per cell (a.u.) cytogram, in which cryptophytes, coccolithophores and Synechococcus spp are discriminated.

Fig 3. Characteristics of the different water masses defined during the DYPHYMA cruise in the EEC. A. Surface salinity. B. Surface temperature $\left({ }^{\circ} \mathrm{C}\right)$. C. Water masses which were discriminated from the salinity vs temperature diagramm: W1 ( ), W2 ( $)$ and $\mathrm{W3}\left({ }^{\circ}\right)$.

Fig 4. Spatio-temporal phytoplankton variability measured by SFCM during the DYPHYMA cruise. A. Phytoplankton abundance (cells $\mathrm{mL}^{-1}$ ). B. Phytoplankton total red fluorescence $\left(10^{5}\right.$ a.u. $\left.\mathrm{mL}^{-1}\right)$ and chlorophyll $a\left(\mu \mathrm{L} \mathrm{L}^{-1}\right)$ concentrations (figures). The 
water masses are superimposed: W1 ( $), \mathrm{W} 2\left({ }^{\circ}\right)$ and $\mathrm{W} 3\left({ }^{\circ}\right)$. The $\mathrm{X}$-axis indicates the distance $(\mathrm{km})$ covered and the time (GMT).

Fig 5. Location of the different phytoplankton assemblages, in the EEC, during the DYPHYMA cruise. Each color corresponds to a different phytoplankton community structure by applying the Bray-Curtis dissimilarity index coupled to the Ward method based on phytoplankton composition from CytoSense.

Fig 6. Relative average contribution of phytoplankton abundance $(\%)$ from all station measured by SFCM within each phytoplankton community. CM1: Community 1. CM2: Community 2. CM3: Community 3. CM4: Community 4.

Average values \pm standard deviation

\begin{tabular}{cccccc}
\hline & Transmittance (\%) & Salinity & Temperature $\left({ }^{\circ} \mathrm{C}\right)$ & $\mathrm{NO}_{3}\left(\mu \mathrm{mol} \mathrm{L}{ }^{-1}\right)$ & $\mathrm{PO}_{4}\left(\mu \mathrm{mol} \mathrm{L}^{-1}\right)$ \\
\hline \hline W1 & $80.60 \pm 3.67$ & $34.58 \pm 0.13$ & $9.97 \pm 0.12$ & $0.16 \pm 0.26$ & $0.29 \pm 0.14$ \\
$\mathrm{~W} 2$ & $73.90 \pm 5.15$ & $34.31 \pm 0.09$ & $10.18 \pm 0.09$ & $0.48 \pm 0.58$ & $0.09 \pm 0.05$ \\
W3 & $88.90 \pm 4.92$ & $35.14 \pm 0.07$ & $10.03 \pm 0.27$ & $1.94 \pm 1.80$ & $0.35 \pm 0.24$
\end{tabular}


Average values $\left(10^{3}\right) \pm$ standard deviation $\left(10^{3}\right)$

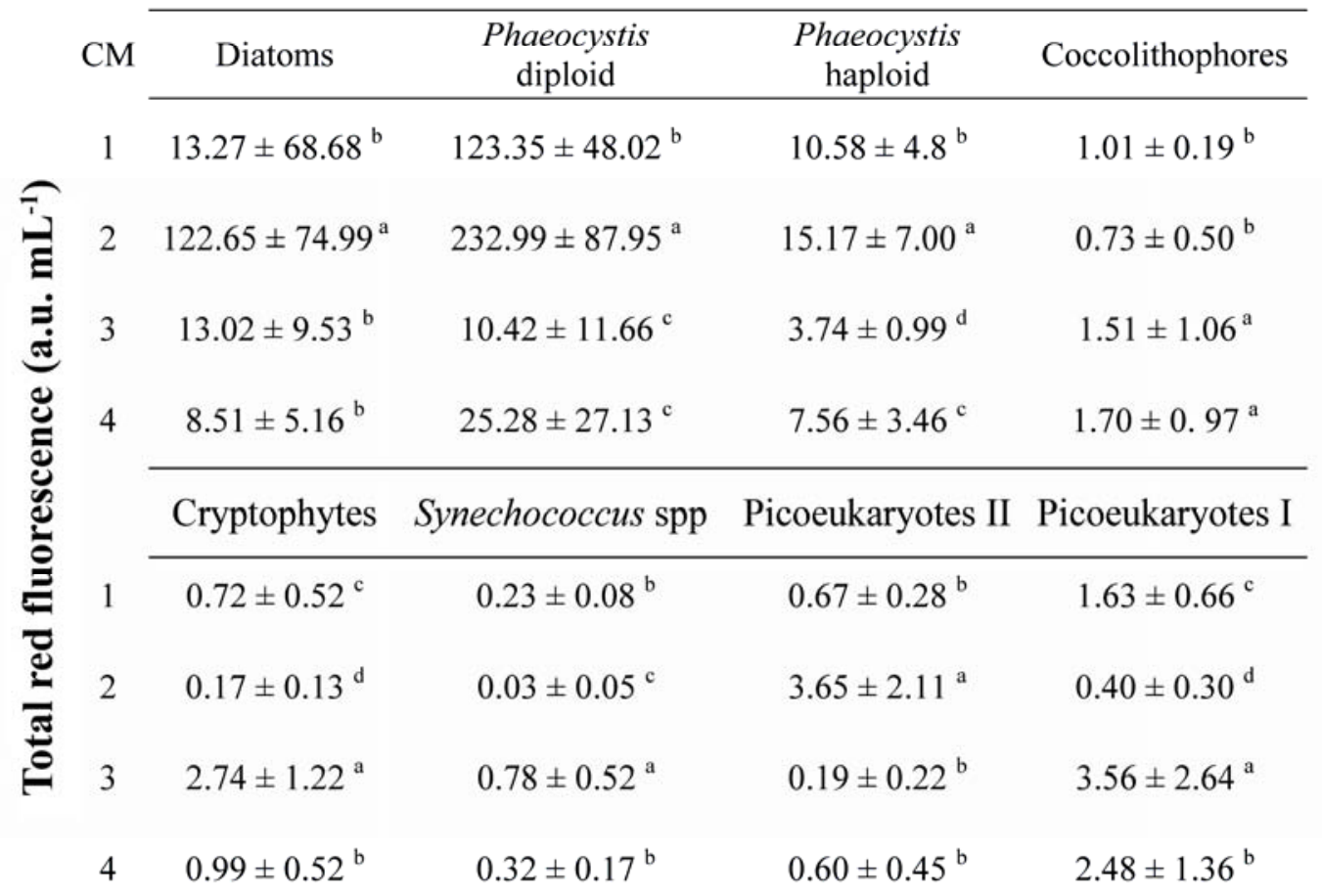

Average values \pm standard deviation

CM Diatoms $\begin{array}{ccc}\text { Phaeocystis } & \text { Phaeocystis } \\ \text { diploid } & \text { haploid } & \text { Coccolithophores }\end{array}$

\begin{tabular}{|c|c|c|c|c|}
\hline 1 & $6.12 \pm 5.19^{b}$ & $10.11 \pm 4.50^{b}$ & $1.21 \pm 0.14^{b}$ & $0.94 \pm 0.18^{\mathrm{a}}$ \\
\hline 2 & $3.80 \pm 0.80^{\mathrm{c}}$ & $15.66 \pm 5.16^{\mathrm{a}}$ & $1.43 \pm 0.40^{a}$ & $0.81 \pm 0.17^{\mathrm{b}}$ \\
\hline 3 & $10.25 \pm 4.85^{\mathrm{a}}$ & $1.76 \pm 1.97^{\mathrm{c}}$ & $1.20 \pm 0.12^{b}$ & $0.90 \pm 0.19^{\mathrm{a}}$ \\
\hline 4 & $9.75 \pm 6.23^{a}$ & $2.29 \pm 2.66^{c}$ & $1.16 \pm 0.14^{b}$ & $0.86 \pm 0.16^{\mathrm{ab}}$ \\
\hline & Cryptophytes & Synechococcus spp & Picoeukayotes II & Picoeukaryotes I \\
\hline 1 & $1.19 \pm 0.41^{\mathrm{c}}$ & $5.10^{-2} \pm 3.10^{-3 b}$ & $0.85 \pm 0.46^{\mathrm{ab}}$ & $0.19 \pm 0.09^{a}$ \\
\hline 2 & $1.88 \pm 1.09^{a b}$ & 4. $10^{-2} \pm 6 \cdot 10^{-3} \mathrm{c}$ & $0.80 \pm 0.13^{b}$ & $0.17 \pm 0.04^{b}$ \\
\hline 3 & $1.93 \pm 0.12^{\mathrm{a}}$ & 6. $10^{-2} \pm 6.10^{-3 \mathrm{a}}$ & $0.93 \pm 0.41^{\mathrm{a}}$ & $0.20 \pm 0.04^{\mathrm{a}}$ \\
\hline
\end{tabular}



$4 \quad 1.60 \pm 0.89^{b}$
5. $10^{-2} \pm 8 \cdot 10^{-3 \mathrm{~b}}$
$0.86 \pm 0.45^{\mathrm{ab}}$
$0.17 \pm 0.05^{\mathrm{ab}}$

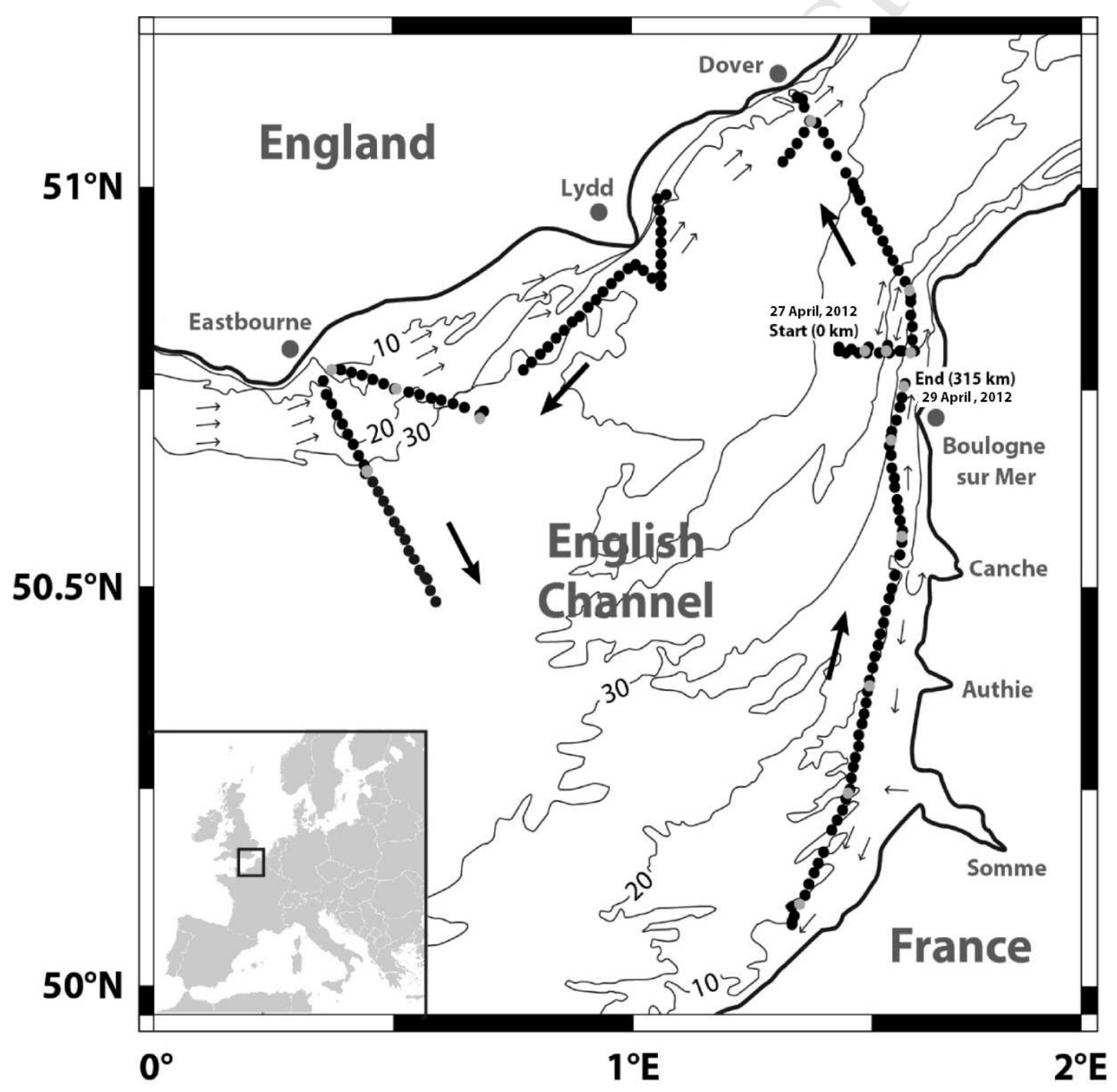




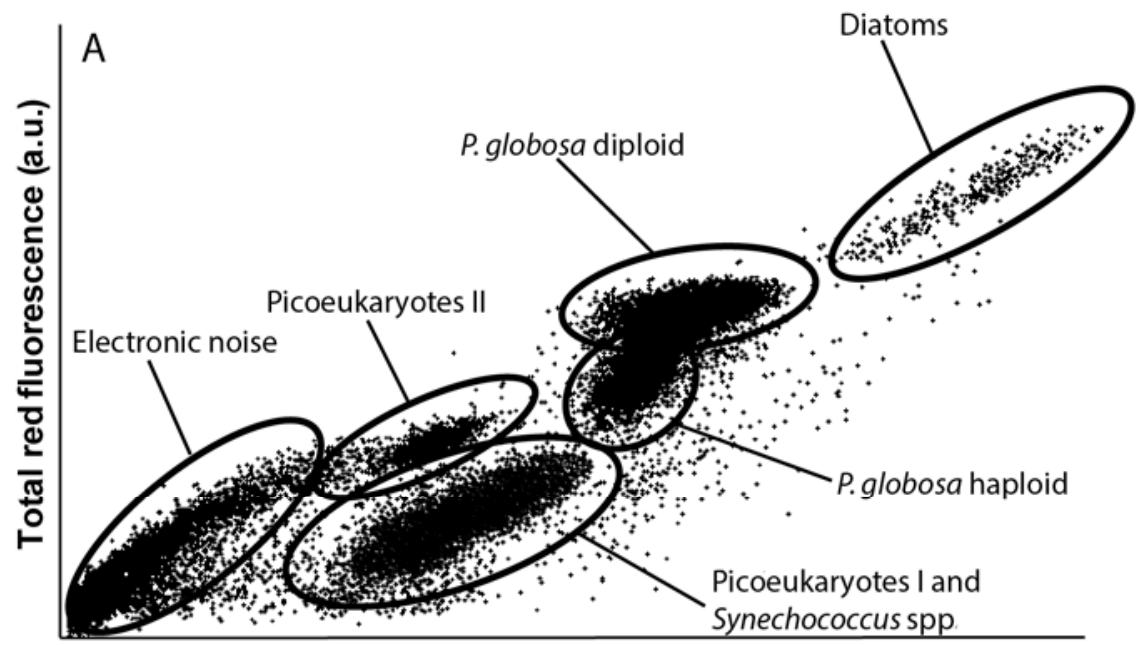

Forward scatter (a.u.)

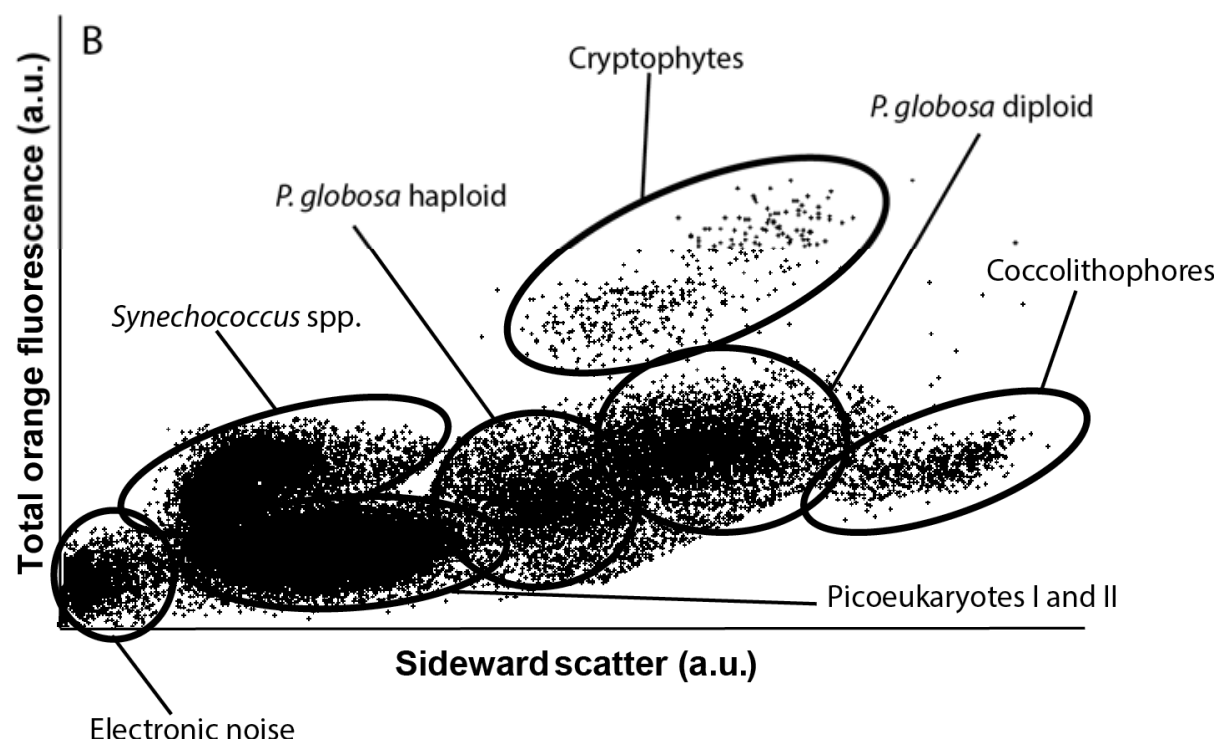




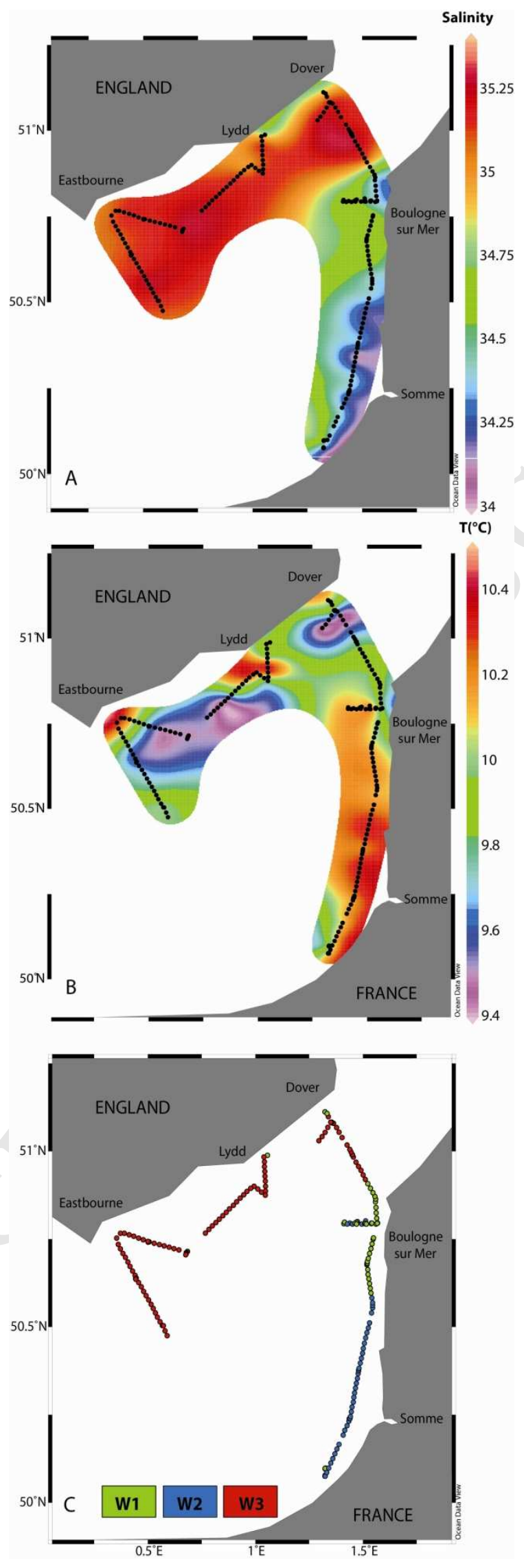



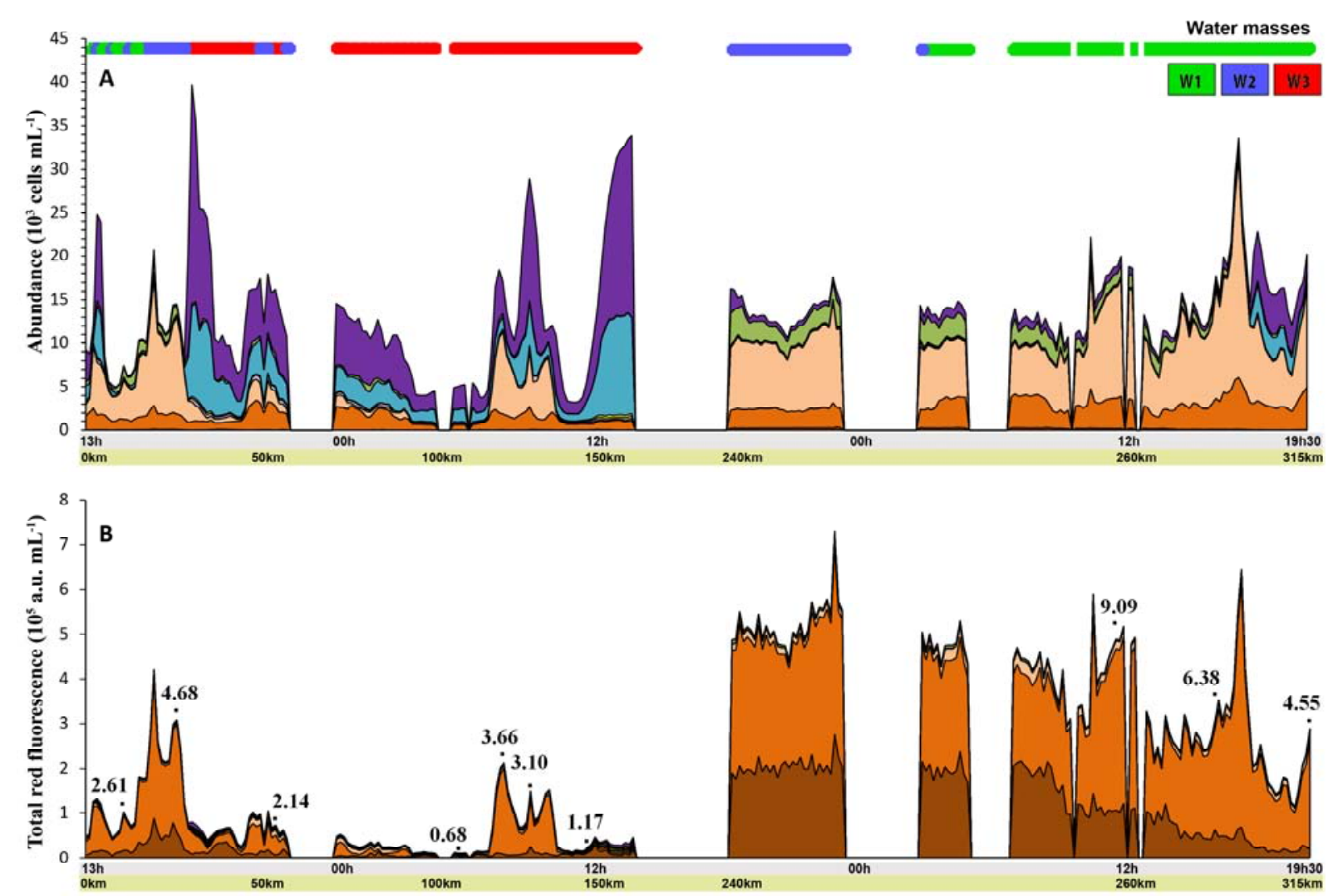

$\square$ Diatoms $\square$ Cryptophytes $\square$ Picoeukaryotes I $\square$ Picoeukaryotes II $\square$ Synechococcus spp. $\square$ P. globosa haploid $\square$ P. globosa diploid $\square$ Coccolithophores 


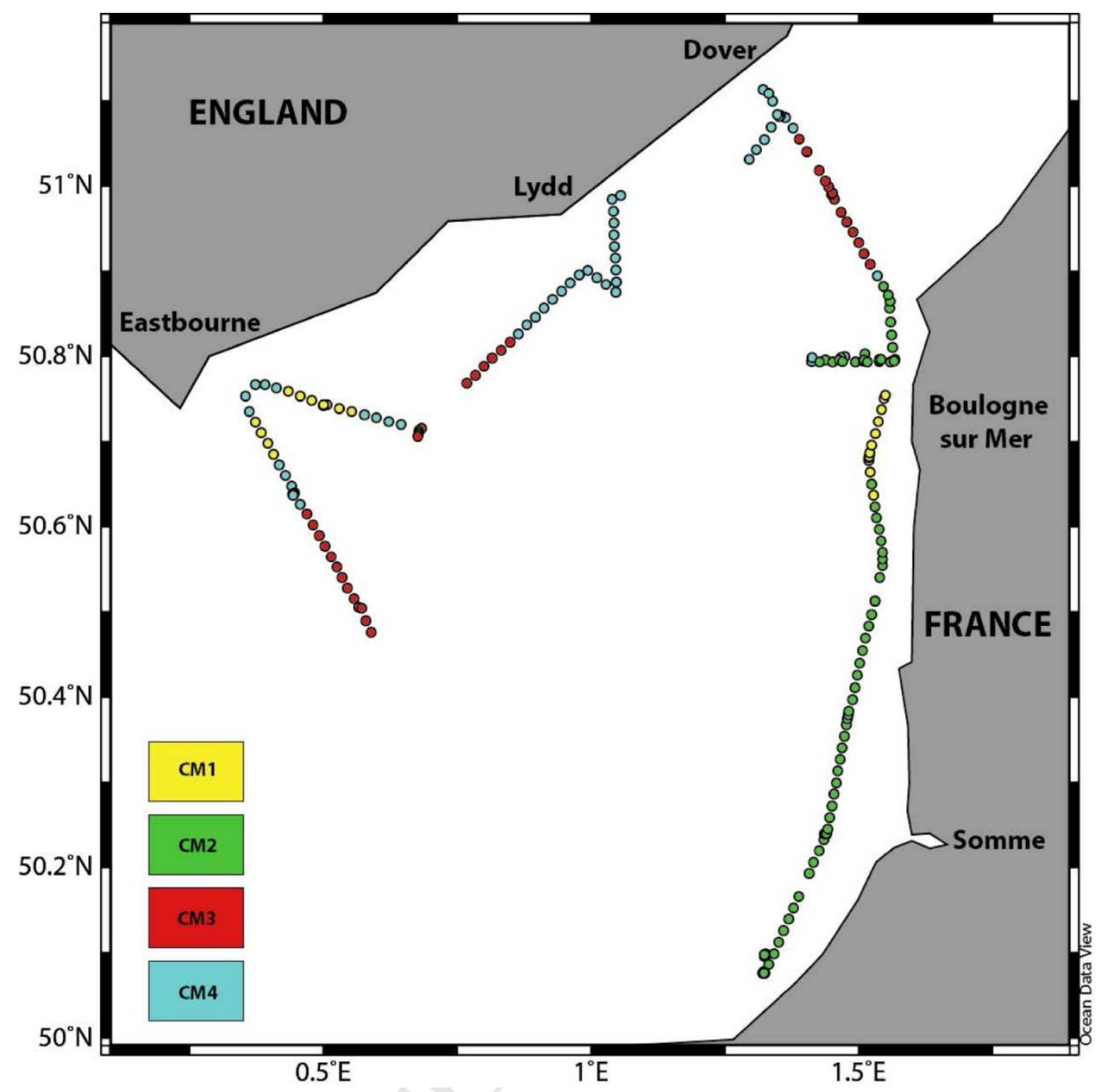




\section{ACCEPTED MANUSCRIPT}
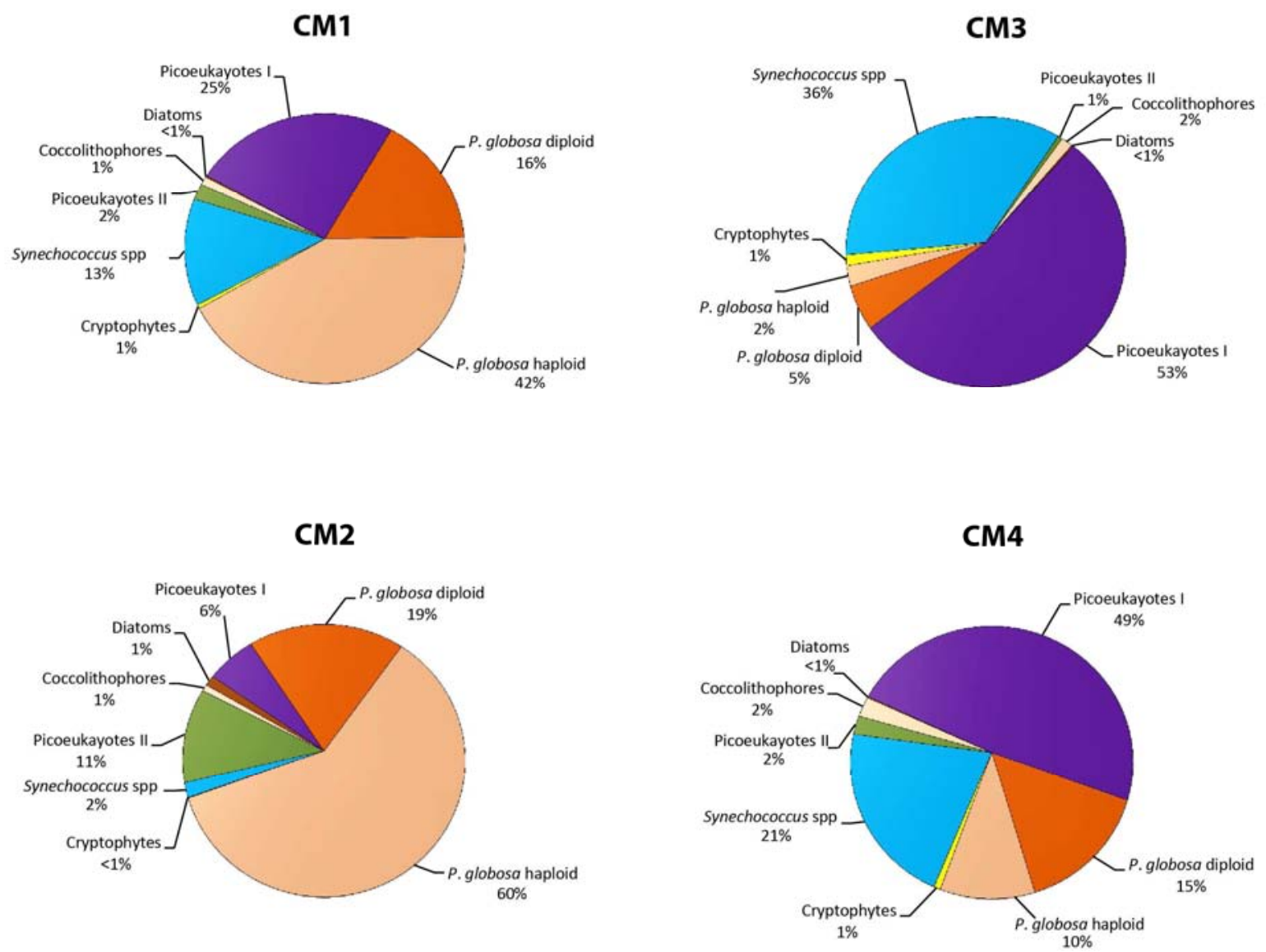